\title{
Professional development in MOOC: Teachers motivation
}

\author{
Literature review: an exploratory study
}

\author{
Bruno Miguel F. Gonçalves \\ Escola Superior de Tecnologia \\ Instituto Politécnico do Cávado e do Ave \\ Barcelos, Portugal \\ bmgoncalves@ipca.pt
}

\author{
Vítor Barrigão Gonçalves \\ Escola Superior de Educação \\ Instituto Politécnico de Bragança \\ Bragança, Portugal \\ vg@ipb.pt
}

\begin{abstract}
The increase in the number and quality of technologies has imposed on education in general new forms of learning, some with less relevance, but others with recognized results in the educational and scientific community. The Massive Open Online Courses (MOOC) are an example of one of these technologies with recognized results because that seems to contribute to the acquisition and mastery of digital competences in the context of the realization of the teaching-learning process supported by the networks. It is in these networks that all the participants in the educational process interact and collaborate with all, cultivate connections, debate the themes, present their criticisms, update their knowledge, acquire new skills, make decisions, but generically develop as members of a connectivist community. Based on these assumptions, in this research we intend to make a review of the literature to identify the aspects that, in detriment of regular education, to encourage the teachers to adopt the MOOC as technology for their professional development and to carry out the process of teaching and learning. Thus, through an exploratory research, characterized as documentary, we use the main sources of information, in this case scientific articles published on the subject to understand the relevance and contribution of the MOOC in an educational universe supported by technologies. In general, the results, although preliminary because of temporal limitations issues in accompanying the rapid evolution of the scientific production of knowledge, suggest that on the one hand the teachers opt for MOOC education for the ease of distance learning; on the other hand, adopt the MOOCs for the acquisition of digital skills oriented to the new challenges.
\end{abstract}

Keywords - digital skills; educational institutions; MOOC; teachers; technological modernization.

\section{INTRODUCTION}

Given its enormous potential, the use of ICT (Information and Communication Technologies) in the teaching-learning process seems to be consensual in the scientific and educational community. However, the integration of these technologies requires a change in practices, especially in what refers to the way these technologies are used in the educational process. The MOOCs are an example of a technological innovation that can translate into an opportunity to change these practices, since they seem to offer the necessary conditions for teacher training in a network. Considering that the growth of information and its accessibility through networks is increasingly evident, it is also a fact that professional development is increasingly linked to learning networks. It is therefore fundamental that teachers continually monitor this change and that, through it, they can develop skills and acquire new knowledge, enabling them to have an effective ICT practice. Thus, the teachers should be prepared for this new technological universe, where technologies assume a preponderant role in their learning process, since they will not only renew their knowledge, but also acquire new skills that will allow them to take advantage of the most recent learning environments, particularly in MOOCs. The present study focuses precisely on these perspective - the MOOC as technology for professional development of teachers and to carry out the process of teaching and learning. For this we use the main sources of information (scientific articles published) to understand the relevance of the MOOC in contemporary education.

\section{TEACHING-LEARNING PROCESS IN MOOC}

\section{A. MOOC: a connectivist learning}

Although the integration of ICT in the teaching-learning process is on the agenda of international organizations, particularly educational institutions, it does not seem possible to understand technological evolution and network society from existing learning theories because they are insufficient. Thus, to frame the learning network, Siemens (the author of connectivism), proposes connectivism as a learning theory for the digital age that approaches knowledge as something distributed in a network of connections. Connectivism is the learning theory that supports MOOCs and "provides a perception of the learning skills and tasks necessary for learners to flourish in the digital age" [1]. Connectivism aims to respond to the needs of 21 st century students and the new realities derived from technological development and social and cultural economic transformations [2] and can be considered as the integration of principles explored by chaos, network, and theories of complexity and self-organization [3].

As connectivist learning is multifaceted, according to the model (Figure 1), learning is described in four domains: accretion, acquisition, transmission and emergency [4]. Learning by accretion: the student seeks knowledge when and where it is needed. It is the real life that guides this kind of learning, through dialogue, workshops, scientific articles, 
reflections on projects we develop, among other activities; Learning by acquisition: the student has the function of defining the knowledge that he wishes to acquire and actively participating in the process in order to guarantee his motivation. Transmission learning is based on the traditional perspective, in which the student acquires knowledge through participation in lectures or courses; Transmission learning: it is used to construct a series of elementary knowledge related to a scientific subject or subject. However, it is considered a poor social and collaborative model; Emergency learning: focuses on reflection and promotes high-level innovation and cognition. It is a model with a very complex implementation on a large scale, since it requires not only good skills and critical thinking on the part of all the students, but also a high level of knowledge of the contents.

Of the types of learning previously described, none can be considered the best or worst option, because each situation is unique and specific. It is therefore fundamental to aggregate several methodologies to meet the learning needs, and for Siemens, it is the communities that can best meet the needs of students in this regard.

\section{B. The importance of learning communities for the colaboration between teachers}

The use of ICT is a determining aspect of learning communities, as it not only facilitates the process of communication, interaction and collaboration between teachers but also promotes learning among all [5]. Thus, learning communities can significantly increase their effectiveness when using digital technologies to consolidate interaction and communication networks within them and to promote and enhance the learning of their members [5]. Based on this assumption, the integration of ICT into the professional development process of teachers in the context of a learning community in the MOOC seems to be fundamental, since teachers need to develop "a comprehensive conception of the subject in relation to technology and what it means to teach with technology" [6].

The importance of learning communities for the collaboration between teachers seems to be evidenced in a set of three dynamics, namely: social dynamics, cultural dynamics and cognitive dynamics. Social dynamic: virtual communities cannot be dissociated from socialization and network interaction [7]. A high level of social presence is required to support the meaningful development of learning among all members of the community [8]. Thus, it is important for course developers, instructors, and participants to know how to create this social connection in learning environments [9]; Cultural dynamic: is related to the cultural development of each group, because "through this microculture, the members of a community develop a common identity" [10]; Cognitive Dynamic: the purpose of this dynamic overcomes social interaction in the search for results [11], such as the ability to construct interpretations based on constant reflection [12]. Each of the dynamics manifests itself according to its degree of intensity, type of community, its own dynamics, level of evolution and maturity.
The growth of collaboration in these learning environments is linked "to the fascination with the new forms of collectives that are being invented around the internet and the Web" [13]. Collaboration in virtual learning environments is a fundamental aspect for the development of communities, particularly the members who constitute them, in this case teachers, because the premise for the virtual learning community is collaboration [14]. It is therefore fundamental to create pedagogies based on sharing, exposing individual perspectives between peers and on collaboration and joint initiative, with the learning community being the object and at the same time the means for this construction" [15].

\section{Teacher skills in networked learning environments}

There are several authors who address the competences of teachers in networked learning environments, such as: e-trainer, instructor or project leader and leader of the group process [16]; the understanding of the functioning of online education, the mastery of technologies and the contents to teach [17]; teacher trainer, teacher "concetor", teacher researcher, teacher tutor, teacher technologist and educational, teacher resource and teacher monitor [18]; social, organizational, pedagogical and technical [19]. In addition to these, the Siemens perspective divides the role of teachers in these network environments into seven functions, namely: amplifying, curating, wayfinding and socially-driven sensemaking, aggregation, filtering, modelling and the persistent presence [20]. Amplifying: as the teacher becomes a knot in the student relations network, it amplifies their influence on them; Curating: the teacher in a network environment becomes a reference, being even dubbed a healer; Wayfinding and socially-driven sensemaking: it is a social process that helps the student to make sense of fragmented information on the network and everything that is available; Aggregation: allows to reveal the structure and content of the course from conversations that unfold; Filtering: resource filtering is an important role of the teacher due to the enormous flow of information; Modeling: it has its roots in learning and consists of a multifaceted process that involves cognitive, social and emotional dimensions; Persistent presence: the teacher needs to be part of a particular social network to connect online with other people so as to know and be known.

Considering the diversity of functions in virtual learning environments, it is fundamental that teachers are able to develop skills and acquire new knowledge that allows them to create conditions for the exercise of the teaching profession and, consequently, to improve the quality of the teachinglearning.

\section{METHODOLOGY}

\section{A. Methodological option \& data collection methods}

In this research of a qualitative nature we review the literature (carried out between 2012 until 2018), using the main sources of information (scientific articles published) to complete the following objectives: (i) Identify the aspects that encourage the teachers to adopt the MOOC as technology for their professional development and to carry out the process of teaching and learning; (ii) Understand the relevance and 
contribution of the MOOC in an educational universe supported by the technologies. The data were collected between November 2, 2018 and January 26, 2019. As a form of limitation and organization of the study were searched on the Web (scientific repositories of universities and polytechnics, B-ON Library, Springer, DOAJ - Directory of Open Access Journals and Scielo Portugal) only the following terms: "Motivations of teachers for the learning supported by MOOC"; "Training teachers in MOOC"; "Roles of teachers in the MOOC"; "Aspects that demonstrate the importance of MOOCs in the teaching-learning process"; "The Teachers and the MOOC". It is interesting to note that these terms were searched only in English as a way of extending the research to the international scientific community.

\section{B. Content analysis: literature review}

The content analysis was developed to identify the content of all the documents and, consequently, to determine the aspects that encourage the teachers to adopt the MOOC as technology for their professional development. In order to ensure the quality and reliability of the collected data we have chosen to consider only scientific articles published.

As a way of categorizing and organizing content analysis, two main categories were established: "motivations of teachers in MOOC" and the "technological, pedagogical and content skills" (this category are in compliance with the main models of professional teacher development available in the literature). These categories were rigorously analyzed in each of the 39 documents identified but only $12(30,76 \%)$ contributed (validated documents) to respond to previously formulated research questions (Table 1$)$. While 8 articles $(66,66 \%)$ relate to the first category (motivations of teachers in MOOC), the remaining 4 articles $(33,33 \%)$ relate to the second category (technological, pedagogical and content skills). All the data are organized, validated (matrix for qualitative data) and processed in WEBQDA software that allowed the analysis of text sources, documents and PDF files (qualitative analysis) based on the two categories established. Subsequently, the final analysis was carried out to standardize the data with support in the framework of qualitative results in order to be able to respond to the research questions formulated.

\begin{tabular}{|c|c|c|}
\hline Id & Article name & Authors \\
\hline A1 & $\begin{array}{l}\text { A Prospective Study on the Application of MOOC in Teacher } \\
\text { Professional Development in China }\end{array}$ & [21] \\
\hline $\mathrm{A} 2$ & Digital Skills Development: MOOC as a tool for teacher training & [22] \\
\hline $\mathrm{A} 3$ & Language Teaching in MOOCs: the Integral Role of the Instructor. & [23] \\
\hline A4 & $\begin{array}{l}\text { MOOC Instructor Motivations, Innovations, and Designs: Surveys, } \\
\text { Interviews, and Course Reviews }\end{array}$ & [24]: \\
\hline A5 & $\begin{array}{l}\text { MOOCs and their Influence on Higher Education Institutions: } \\
\text { Perspectives from the Insiders }\end{array}$ & [25] \\
\hline A6 & $\begin{array}{l}\text { MOOCs as a Disruptive Innovation to Develop Digital Competence } \\
\text { Teaching: A Micromasters Program edX Experience }\end{array}$ & [26] \\
\hline A7 & $\begin{array}{l}\text { MOOCs for Teacher Professional Development: Reflections, and } \\
\text { Suggested Actions }\end{array}$ & [27] \\
\hline A8 & $\begin{array}{l}\text { Motivation and Engagement in MOOCs: How to Increase Learning } \\
\text { Motivation by Adapting Pedagogical Scenarios? }\end{array}$ & [28] \\
\hline A9 & $\begin{array}{l}\text { Motivation to learn in massive open online courses: Examining } \\
\text { aspects of language and social engagement }\end{array}$ & [29] \\
\hline A10 & Role of Teacher in Personal Learning Environments & [30] \\
\hline A11 & $\begin{array}{l}\text { Teachers' Roles in Light of Massive Open Online Courses (MOOCs): } \\
\text { Evolution and Challenges in Higher Distance Education }\end{array}$ & [31] \\
\hline A12 & $\begin{array}{l}\text { Why Study on a MOOC? The Motives of Students and } \\
\text { Professionals }\end{array}$ & [32] \\
\hline
\end{tabular}

Figure 1. Content analysis (validated documents)
It is evident that the research could be more extensive, however due to temporal limitations, unfortunately it was not possible to extend it to other fields.

\section{DISCUSSION OF RESULTS}

In the content analysis of the 12 scientific articles, a set of aspects were identified that highlight the aspects that motivate the teachers to adopt the MOOC as technology for their professional development and also some of the competences that teachers should have in this type of learning environments.

A1 [21]:

- Enhance teachers' learning experience and meet their various needs;

- $\quad$ Promote the reform on teacher education to some extent;

- Makes it possible for teachers to have classes at any time at any place, which breaks the limitation of synchronic education;

- With MOOC, every education-related party can contribute to its quality improvement;

- Teachers can exchange and cooperate with other teachers, scholars and experts in education, and they can also achieve more thorough communication with students to gain valuable feedback.

A2 [22]:

- Planning and design;

- Instruction and learning;

- Communication and interaction;

- Management and administration;

- ICT use.

A3 [23]:

- MOOC structure designer-developer/ Organizer;

- Content expert/ Content creator/ Content facilitator;

- Assessment designer/ Evaluator;

- Communication tools and structure designer;

- Facilitators

- Curators,

- Researcher.

A4 [24]:

- Curiosity about MOOCs;

- Interest in nontraditional ways of teaching;

- Experimentation with MOOCs;

- Learning about course design from the MOOC experience;

- Democratizing of education;

- $\quad$ Showing off research and teaching;

- University marketing;

- Building their personal reputation;

- Problem-based learning;

- Service learning;

- Integrating interactive media;

- Peer review process.

A5 [25]

- Require creativity, innovation, time, and a great deal of effort; 
- MOOCs hold a positive attitude to the open education approach;

- Creation of materials that showcase their work, and at the same time provide free education to those in need;

- Smoothen the digital transformation of university by not only keeping their digital materials in online repositories, but also organizing them for repurposing and reusing, towards an optimal use of them;

- Educators find it challenging to deliver their content in new formats, such as communicating through video, and writing for large, diverse, and unknown audiences.

A6 [26]:

- Critical thinking, and problem-solving skills to improve digital competence;

- Participate in live collaborative discussions;

- Discussing specific subjects;

- $\quad$ Post doubts and comments;

- $\quad$ Shared points of view;

- Discussing shared experiences with their peers and tutors;

- Interacting with learners from all over the world;

- Diversity of experiences, knowledges, languages and cultures.

A7 [27]:

- The MOOC attracting smart people who want to advance their professional development [33];

- MOOCs offer a powerful platform for education and development with cost savings and greater efficiency [34];

- MOOCs promise to support teacher professional development by providing accessible, flexible and fasttrack completion of certified courses [35];

- Participating in MOOCs can help to develop certain teaching, digital, and academic skills (Urrutia et al., 2016);

- $\quad$ MOOCs can train a large number of untrained or less trained teachers to become more professional in their practices and approaches (Laurillard \& Kennedy, 2017);

- MOOCs provide a professional development with alternative credentials recognized by employers [37].

A8 [28]:

- Pedagogical strategies approach;

- Personalization and/or adaptivity approach;

- Gamification approach;

- Technological approach.

A9 [29]:

- Their motivation to learn is based on their desire to solve real;

- Desire to meet people with similar expertise and interests in order to share ideas and collaborate;

- Their motivation to learn is based on their desire to contribute to the advancement of their society and country;
- Their motivation to learn is based on their desire to staying informed about the latest innovations;

- Seek to expand their school curriculum with worldwide knowledge.

A10 [30]:

- Teacher need to be innovative and knowledgeable regarding where and how to locate the resources he needs;

- Planner, designer, instructional/learning designer, programmer;

- Lecturer/instructor, demonstrator, theorizer, master artist, learner, critic, agitator, motivator, mentor;

- Coordinator, facilitator, partner, communicator, moderator, convener, salesperson, collaborator, participant, collector;

- Leader/change agent, administrative manager/bureaucrat, curator, coach, guide, concierge, goal setter, evaluator;

- Alchemist, sharer, network administrator, technician, technologist, media publisher/editor.

A11 [31]:

- Analytics (access monitoring, success and completion rates, learners' satisfaction surveys);

- $\quad$ Assessment of learning (marking assignments, providing feedback to students);

- Creation of other interaction spaces with or among learners (blog, social networks, etc);

- Dynamization of course forums (to promote learners participation);

- Participation in course forums to solve non content related questions (deadlines for example);

- Participation in course forums to solve content related questions;

- Design of peer-assessment activities;

- Design of automated assessment activities;

- Content curation (selection of resources and links, additional contents);

- Preparation of educational resources (text, video, ...);

- General course design (schedule, decisions about content and structure);

- Course director / coordinator.

A12[32]:

- Relevance to current role;

- Learning content;

- Relevance to future career;

- Interest in the topic;

- Other motivation (prestige, certification, MOOC study, (zero) cost, opportunity to learn in English).

In the first category "motivations of teachers in MOOC" there is a wide range of motivations for which teachers have a preference for MOOCs in dropping out of regular education, but the main one is undoubtedly innovation and the possibility of acquiring digital competences simultaneously with learning the MOOC course itself. In the second category "technological, pedagogical and content skills" are identified several skills that 
teachers should have in digital learning environments, in this case in the MOOC. These skills are in accordance with the literature review done at the beginning of this work (Collison et al., 2001; Belloni, 2001; Daele \& Lusalusa, 2002; Siemens, 2010). This skills enables them to create conditions for the practice of teaching profession to improve effective practice with ICT. It is, therefore, fundamental the commitment of all teachers in the use of the various digital tools available in the MOOC.

\section{CONCLUSIONS}

The realization of this research allowed to identify the aspects that encourage the teachers to adopt the MOOC as technology for their professional development and to carry out the process of teaching and learning. These aspects portray the motivation of teachers for learning in the MOOC and also seem to determine the option of the MOOC as a technology that supports the professional development process of teachers, making this process more dynamic, motivating, collaborative and extended to all education professionals. The objective will always be the creation of conditions for the exercise of the teaching profession and, consequently, for the improvement of the quality of the teaching-learning process. For this, it is also important to mobilize teachers to develop the technological skills identified. Being a teacher without knowledge of digital tools does not seem possible today. Thus, each teacher should have the sensitivity to improve digital skills through participation in continuous training in the MOOCs and in learning communities, since it is the connectivism that aims to respond to the needs of this century and the new realities derived from technological

The motivations and the digital skills allowed to understand the relevance and contribution of the MOOC in educational universe supported by technologies. This contribution seems to be fundamental to the change in teachers' practices, as a technological innovation and as a reform of the professional development process of teachers. However, it is very important that teachers feel prepared for this digital reform, where technologies assume a preponderant role in their continuing education, but especially in the planning, development and evaluation of the teaching-learning process.

Finally we can conclude that the two categories are associated, since one does not prevail without the other; one of the main motivations of teachers in the MOOC is the acquisition of digital competences, but in order to acquire these competences it is necessary that the teacher is motivated, available to learn, to use and be open to new challenges. Motivation is undoubtedly the fundamental pillar for the realization of learning and learning today can only be achieved in full if the teacher is qualified for the digital exercise of his profession.

\section{REFERENCES}

[1] G. Siemens, "Connectivism: a theory of learning for the digital age," Int. J. Instr. Technol. Distance Learn., vol. 2, no. 1, 2005.

[2] G. Siemens, "Learning ecology, communities, and networks: Extending the classroom," elearnspace, last Ed. Oct. 17th, 2003.

[3] G. Siemens, "Conectivismo. Uma teoria de aprendizagem para a idade digital." 2004.

[4] G. Siemens, "Connectivism: Learning theory or pastime of the selfamused? Elearnspace,” Retrouvé Juillet, vol. 29, p. 2010.

[5] C. Coll, "Las comunidades de aprendizaje. Nuevos horizontes para la investigación y la intervención en psicología de la educación," in $I V$ Congreso Internacional de Psicología y Educación, Almeria, 2004, vol. 30 .

[6] M. L. Niess, "Preparing teachers to teach science and mathematics with technology: Developing a technology pedagogical content knowledge," Teach. Teach. Educ., vol. 21, no. 5, pp. 509-523, 2005.

[7] J. Salinas, "Comunidades virtuales y aprendizaje digital," $C D-R O M$ Edutec, vol. 54, no. 2, pp. 1-21, 2003.

[8] L. Rourke, T. Anderson, D. R. Garrison, and W. Archer, "Assessing social presence in asynchronous text-based computer conferencing," Int. J. E-Learning Distance Educ., vol. 14, no. 2, pp. 50-71, 2001.

[9] S. R. Aragon, "Creating social presence in online environments," New Dir.adult Contin. Educ., no. 100, pp. 57-68, 2003.

[10] P. Dillenbourg, C. Poirier, and L. Carles, “Communautés virtuelles d'apprentissage: e-jargon ou nouveau paradigme? In A. Taurisson \& A. Senteni(Eds.), Pédagogies.Net. L'essor des communautés virtuelles d'apprentissage ." Sainte-Foy: Presses de L'Université du Québec., p. pp.11-72, 2003.

[11] R. M. Wallace, "Online learning in higher education: A review of research on interactions among teachers and students," Educ. Commun. Inf., vol. 3, no. 2, pp. 241-280, 2003.

[12] D. R. Garrison and T. Anderson, "El e-learning en el siglo XXI: Investigación y práctica,” Barcelona: Octaedro., 2005.

[13] F. Henri and B. Pudelko, "La recherche sur la communication asynchrone: de l'outil aux communautés," Les communautés délocalisées d'enseignants, pp. 12-44, 2002.

[14] M. Pazos, A. Pérez, and J. Salinas, "Comunidades virtuales: de las listas de discusión a las comunidades de aprendizaje," in Comunicación presentada en EDUTEC 2001. Congreso Internacional de Tecnología, Educación y Desarrollo Sostenible. Murcia, 2001, pp. 17-19.

[15] P. Dias, "Desenvolvimento de objetos de aprendizagem para plataformas colaborativas.," Atas do VII Congreso Iberoamericano de Informatica Educativa. Monterrey: Universidad de Monterrey, pp. 12-33, 2004.

[16] G. Collison, B. Elbaum, S. Haavind, and R. Tinker, "EFFECTIVE STRATEGIES FOR MODERATORS," Q. Rev. Distance Educ., vol. 2, no. 4, pp. 397-401, 2001.

[17] G. Salmon, E-actividades: el factor clave para una formación en línea activa. Editorial UOC, 2004.

[18] M. Belloni, "Educação a Distância.” Campinas: Autores associados., 2001.

[19] A. Daele and S. Lusalusa, "Chapitre 11. Quels nouveaux rôles pour les formateurs d'enseignants?," in Technologie et innovation en pédagogie, De Boeck Supérieur, 2002, pp. 141-147.

[20] G. Siemens, Teaching in Social and Technological Networks. Connectivism blog entry on Feb. 16, 2010. Retrieved Nov 30, 2011.

[21] Z. Ji and Y. Cao, "A Prospective Study on the Application of MOOC 
in Teacher Professional Development in China.," Univers. J. Educ. Res., vol. 4, no. 9, pp. 2061-2067, 2016.

[22] N. Rivera and M. S. Ramirez, "Digital skills development: MOOC as a tool for teacher training," in Proceedings from International Conference of Education, Research, and Innovation (ICERI2015), 2015.

[23] M. D. C. Larreta-Azelain, "5 Language Teaching in MOOCs: the Integral Role of the Instructor," in Language MOOCs, Sciendo Migration, 2014, pp. 67-90.

[24] A. S. Curtis J. Bonk, Meina Zhu, "MOOC Instructor Motivations, Innovations, and Designs: Surveys, Interviews, and Course Reviews," Am. Educ. Res. Assoc. Annu. Meet. New York City, NY, 2018.

[25] M. Leon Urrutia, S. Fielding, and S. White, "Professional development through MOOCs in higher education institutions: Challenges and opportunities for $\mathrm{PhD}$ students working as mentors," J. Interact. Media Educ., vol. 1, pp. 1-11, 2016.

[26] M. De La Roca, M. Morales, A. M. Teixeira, F. Sagastume, R. H. Rizzardini, and R. Barchino, "MOOCs as a Disruptive Innovation to Develop Digital Competence Teaching: A Micromasters Program edX Experience," Eur. J. Open, Distance E-learning, vol. 21, no. 2, 2018.

[27] P. Misra, "MOOCs for teacher professional development: reflections and suggested actions," Open Prax., vol. 10, no. 1, pp. 67-77, 2018.

[28] A. Bakki, L. Oubahssi, C. Cherkaoui, and S. George, "Motivation and Engagement in MOOCs: How to Increase Learning Motivation by Adapting Pedagogical Scenarios?," in Design for Teaching and Learning in a Networked World, Springer, 2015, pp. 556-559.

[29] M. Barak, A. Watted, and H. Haick, "Motivation to learn in massive open online courses: Examining aspects of language and social engagement," Comput. Educ., vol. 94, pp. 49-60, 2016.

[30] Z. A. Shaikh and S. A. Khoja, "Role of teacher in personal learning environments," Digit. Educ. Rev., no. 21, pp. 23-32, 2012.

[31] I. Gil-Jaurena and D. Domínguez, “Teachers' roles in light of massive open online courses (MOOCs): Evolution and challenges in higher distance education," Int. Rev. Educ., vol. 64, no. 2, pp. 197-219, 2018

[32] C. Milligan and A. Littlejohn, "Why study on a MOOC? The motives of students and professionals," Int. Rev. Res. Open Distrib. Learn., vol. 18, no. 2, 2017.

[33] K. Coffman, "The professional development advantages of MOOCs.," 2015.

[34] S. Florentine, "ways MOOCs are changing professional development. CIO.” 2015.

[35] A. Kumari, "An online platform for teacher professional development. Asian Journal of Multidisciplinary Studies," vol. 4, no. 5, pp. 102-107, 2016.

[36] E. Laurillard, D., \& Kennedy, "Moocs can still bring higher education to those who really need it," Times High. Educ., 2017.

[37] M. Amigot, "MOOCs evolve into professional development courses with alternative credentials.," IBL Stud., 2017. 